\title{
ANALISIS QUALITY OF SERVICE (QOS) PADA JARINGAN INTERNET SMK NEGERI 7 JAKARTA
}

\author{
Aprianto Budiman', M. Ficky Duskarnaen², Hamidillah Ajie ${ }^{3}$ \\ ${ }^{1}$ Mahasiswa Prodi PendidikanTeknik Informatika dan Komputer, Teknik Elektro, FT - UNJ \\ ${ }^{2,3}$ Dosen Prodi Pendidikan Teknik Informatika dan Komputer, Teknik Elektro, FT - UNJ \\ 11apres46@gmail.com, ${ }^{2}$ duskarnaen@unj.ac.id, ${ }^{3}$ hamidillah@unj.ac.id
}

\begin{abstract}
Abstrak
Hampir semua kegiatan di SMK Negeri 7 Jakarta memanfaatkan fasilitas Internet. Baik itu untuk proses kegiatan belajar mengajar, maupun pada bagian staff tata usaha. Untuk mendukung semua kegiatan tersebut diperlukan kinerja jaringan yang baik dan handal. Koneksi jaringan yang buruk pastinya akan menggagu proses kegiatan tersebut. Penerapan Quality of Service $(Q o S)$ merupakan sebuah solusi dari masalah diatas Quality of Service (QoS) merupakan teknik untuk mengelola bandwidth, delay, packet loss dan jitter untuk aliran dalam jaringan. Tujuan dari mekanisme QoS adalah mempengaruhi setidaknya satu diantara empat parameter dasar QoS yang telah ditentukan. Untuk mengetahui seberapa besar nilai QoS pada jaringan Internet SMK Negeri 7 Jakarta, maka harus dilakukan sebuah analisis parameter QoS. Analisis Quality of Service pada jaringan Internet SMK Negeri 7 Jakarta menekankan proses monitoring dan pengukuran parameter QoS yaitu throughput, delay, packet loss dan jitter. Tools yang digunakan untuk pengukuran parameter QoS adalah Axence Net Tools Pro 5.0 dan bandwidth monitor speedtest apps. Hasil akhir yang didapatkan setelah melakukan pengukuran QoS adalah jaringan Internet SMK Negeri 7 Jakarta masuk pada kategori sedang berdasarkan standarisasi TIPHON dengan nilai indeks 2,14.
\end{abstract}

Kata kunci : Quality of Service, Bandwidth, Delay, Packet Loss

\section{Pendahuluan [Times New Roman 10, bold]}

Seiring berkembangnya ilmu pengetahuan dan teknologi akan menyebabkan kebutuhan manusia dalam memperoleh informasi semakin meningkat. Teknologi yang berkembang pesat akan memberikan keuntungan bagi manusia dalam mengakses informasi yang dibutuhkan, seperti waktu mendapatkan informasi menjadi lebih singkat dan kemudahan dalam mencari informasi tersebut. Salah satu cara dalam memperoleh informasi adalah jaringan internet dimana teknologi tersebut merupakan hal yang menjadi perhatian utama bagi teknologi manusia.

Internet dibutuhkan dalam setiap lingkungan. Salah satunya yaitu dalam lingkungan pendidikan. Sekolah Menengah Kejuruan Negeri 7 Jakarta menggunakan fasilitas Internet sebagai penunjang sarana dan prasarana dalam kegiatan belajar dan mengajar. Oleh karena itu sangat penting bagi pihak sekolah memberikan kualitas layanan jaringan yang baik agar proses kegiatan belajar tidak terhambat. SMK Negeri 7 Jakarta adalah sekolah menengah kejuruan yang memiliki 4 program keahlian, antara lain Persiapan Grafika, Produksi Grafika, Multimedia dan Teknik Komputer dan Jaringan. Sekolah ini beralamat di Jl. Tenggiri No. 1, Rawamangun, Jakarta Timur. SMK Negeri 7 mendapatkan nilai akreditasi tinggi yaitu A. Selain itu sekolah ini mendapatkan banyak prestasi, baik di bidang akademik maupun non akademik.

SMK Negeri 7 Jakarta memanfaatkan fasilitas Internet untuk memudahkan baik siswa maupun guru dalam kegiatan belajar mengajar. Staff TU menggunakan fasilitas Internet untuk melayani berbagai keperluan sekolah, seperti absensi, administrasi sekolah dan lain sebagainya. Terjadinya masalah atau koneksi jaringan yang buruk dapat mengganggu proses kegiatan belajar mengajar di sekolah tersebut. Guru biasanya memberikan materi melalui jaringan internet dengan memberikan ebook dan juga menggunakan video pembelajaran dari internet. Untuk mendapatkan kualitas jaringan yang baik diperlukan sebuah teknik atau mekanisme untuk mengelola jaringan tersebut. Teknik yang dimaksud adalah Quality of Service. Pada Quality of Service terdapat parameter yang menentukan baik atau buruknya suatu jaringan. Parameter tersebut antara lain, throughput, delay, packet loss dan jitter..

\section{Dasar Teori}

\subsection{Quality of Service}

Quality of Service adalah teknik untuk mengelola bandwidth, delay, dan packet loss untuk aliran dalam jaringan. Tujuan dari mekanisme QoS adalah mempengaruhi setidaknya satu diantara empat parameter dasar QoS yang telah ditentukan. QoS didesain untuk membantu end user (client) 
menjadi lebih produktif dengan memastikan bahwa user mendapatkan performansi yang handal dari aplikasi-aplikasi berbasis jaringan. QoS mengacu pada kemampuan jaringan untuk menyediakan layanan yang lebih baik pada trafik jaringan tertentu melalui teknologi yang berbeda-beda. QoS merupakan suatu tantangan yang besar dalam jaringan berbasis IP dan internet secara keseluruhan.

Tabel 2.1 Indeks Parameter QoS

\begin{tabular}{|c|c|c|}
\hline Nilai & Presentase $\mathbf{( \% )}$ & Indeks \\
\hline $3,8-4$ & $100 \%$ & Sangat bagus \\
\hline $3-3,79$ & $75-94,75 \%$ & Bagus \\
\hline $2-2,99$ & $50-74,75 \%$ & Sedang \\
\hline $1-1,99$ & $25-49,75 \%$ & Buruk \\
\hline
\end{tabular}

(Sumber : TIPHON)

Parameter QoS yang digunakan :

1. Throughput

Throughput merupakan jumlah total kedatangan paket yang sukses yang diamati pada destination selama interval waktu tertentu dibagi oleh durasi interval waktu tersebut. Throughput merupakan kemampuan sebenarnya suatu jaringan dalam melakukan pengiriman data. Biasanya throughput selalu dikaitkan dengan bandwidth karena throughput memang bisa disebut juga dengan bandwidth dalam kondisi yang sebenarnya.

Tabel 2.2 Kategori Throughput

\begin{tabular}{|c|c|c|}
\hline $\begin{array}{c}\text { Kategori } \\
\text { Throughput }\end{array}$ & Indeks & Throughput \\
\hline Sangat Bagus & $\begin{array}{c}76- \\
100 \%\end{array}$ & 4 \\
\hline Bagus & $51-75 \%$ & 3 \\
\hline Sedang & $26-50 \%$ & 2 \\
\hline Buruk & $25 \%$ & 1 \\
\hline
\end{tabular}

(Sumber : TIPHON)

2. Delay

Packet loss didefinisikan sebagai kegagalan transmisi paket IP mencapai tujuannya. Kegagalan paket tersebut mencapai tujuan, dapat disebabkan oleh beberapa kemungkinkan, diantaranya yaitu :

1.Terjadinya overload trafik didalam jaringan.

2.Tabrakan (congestion) dalam jaringan.

3.Error yang terjadi pada media fisik.

4.Kegagalan yang terjadi pada sisi

penerima antara lain bisa disebabkan

karena overflow yang terjadi pada buffer.

Tabel 2.3 Kategori Packet Loss

\begin{tabular}{|c|c|c|}
\hline $\begin{array}{c}\text { Kategori } \\
\text { Degedrasi }\end{array}$ & $\begin{array}{c}\text { Packet } \\
\text { Loss }\end{array}$ & Indeks \\
\hline Sangat Bagus & $0-2 \%$ & 4 \\
\hline Bagus & $3-14 \%$ & 3 \\
\hline Sedang & $15-24 \%$ & 2 \\
\hline
\end{tabular}

\begin{tabular}{|c|c|c|}
\hline Buruk & $>25 \%$ & 1 \\
\hline \multicolumn{3}{|c|}{ (Sumber : TIPHON) } \\
\hline
\end{tabular}

3. Packet Loss

Delay adalah waktu tunda suatu paket yang diakibatkan oleh proses transmisi dari satu titik ke titik lain yang menjadi tujuannya. Delay di dalam jaringan dapat digolongkan sebagai berikut :

1. Packetization delay

Delay yang disebabkan oleh waktu yang diperlukan untuk proses pembentukan paket IP dari informasi user. Delay ini hanya terjadi sekali saja, yaitu di sumber informasi.

2. Queuing delay

Delay ini disebabkan oleh waktu proses yang diperlukan oleh router dalam menangani transmisi paket di jaringan. Umumnya delay ini sangat kecil, kurang lebih sekitar 100 micro second.

\section{Delay propagasi}

Proses perjalanan informasi selama di dalam media transmisi, misalnya kabel SDH, coaxial atau tembaga, menyebabkan delay yang disebut dengan delay propagasi.

Tabel 2.4 Kategori Delay

\begin{tabular}{|c|c|c|}
\hline Kategori Latency & Delay & Indeks \\
\hline Sangat Bagus & $<150 \mathrm{~m} / \mathrm{s}$ & 4 \\
\hline Bagus & $150 \mathrm{~s} / \mathrm{d} 300 \mathrm{~m} / \mathrm{s}$ & 3 \\
\hline Sedang & $300 \mathrm{~s} / \mathrm{d} 450 \mathrm{~m} / \mathrm{s}$ & 2 \\
\hline Buruk & $>450 \mathrm{~m} / \mathrm{s}$ & 1 \\
\hline
\end{tabular}

(Sumber : TIPHON)

4. Jitter

Jitter merupakan variasi delay antar paket yang terjadi pada jaringan IP. Besarnya nilai jitter akan sangat dipengaruhi oleh variasi beban trafik dan besarnya tumbukan antar paket (congestion) yang ada dalam jaringan IP. Semakin besar beban trafik di dalam jaringan akan menyebabkan semakin besar pula peluang terjadinya congestion dengan demikian nilai jitter akan semakin besar. Semakin besar nilai jitter akan mengakibatkan nilai QoS akan semakin turun. Untuk mendapatkan nilai QoS jaringan yang baik, nilai jitter harus dijaga seminimum mungkin.

Tabel 2.5 Kategori Jitter

\begin{tabular}{|c|c|r|}
\hline $\begin{array}{c}\text { Kategori } \\
\text { Degradasi }\end{array}$ & Peak Jitter & Indeks \\
\hline Sangat Bagus & $0 \mathrm{~m} / \mathrm{s}$ & 4 \\
\hline Bagus & $1 \mathrm{~s} / \mathrm{d} 75 \mathrm{~m} / \mathrm{s}$ & 3 \\
\hline Sedang & $\begin{array}{c}76 \mathrm{~s} / \mathrm{d} 125 \\
\mathrm{~m} / \mathrm{s}\end{array}$ & 2 \\
\hline Buruk & $>225 \mathrm{~m} / \mathrm{s}$ & 1 \\
\hline \multicolumn{2}{|c}{ (Sumber : TIPHON) }
\end{tabular}




\subsection{Model Layanan Quality of Service}

1. Best-Effort Model

Best-Effort Service adalah model layanan tunggal yang menerapkan pengiriman data kapanpun saat diperlukan, dalam jumlah berapapun dan tanpa meminta izin akses atau menginformasikan jaringan terlebih dahulu. Pada Best-Effort Service bisa diartikan usaha jaringan untuk mengirimkan paket data semaksimal mungkin, tanpa ada jaminan apa-apa terhadap reliabilitas, delay, atau throughput. Jika ada sebuah data yang ingin dikirim, maka data tersebut akan dikirim segera begitu media perantara siap dan tersedia. Data akan dihantarkan sebisa mungkin untuk sampai ke tujuan jika hilang ditengah jalan atau tertunda dengan waktu yang cukup lama di dalam perjalanannya, maka tidak ada pihak manapun perangkat yang bertanggung jawab.

\section{Integrated Service Model (IntServ)}

Intergrated Service Model atau disingkat IntServ merupakan model layanan ganda yang dapat mendukung beberapa kebutuhan QoS. Dalam model QoS aplikasi meminta jenis layanan tertentu dari jaringan sebelum mengirim data. Permintaan dibuat berdasarkan sinyal yang jelas, dengan menginformasikan profil traffic jaringan dan meminta jenis layanan tersebut yang dapat mencakup bandwidth dan delay. Model IntServ diharapkan untuk mengirim data hanya setelah mendapat informasi dari jaringan dan juga dapat mengirimkan data yang ada di dalam profil traffic jaringan.

\section{Differentiated Service Model (DiffServ)}

Differentiated Service Model atau biasa disebut DiffServ merupakan model layanan ganda yang dapat memenuhi standarisasi QoS yang berbeda. Model QoS ini bekerja dengan cara melakukan klasifikasi terlebih dahulu terhadap semua paket yag masuk kedalam sebuah jaringan. Pengklasifikasian ini dilakukan dengan cara menyisipkan sebuah informasi tambahan yang khusus untuk keperluan pengaturan QoS dalam header IP pada setiap paket. Setelah paket diklasifikasikan pada perangkat-perangkat jaringan terdekatnya, jaringan akan menggunakan klasifikasi ini untuk menentukan bagaimana traffic data ini diperlakukan, misalnya perlakuan queuing, shaping, dan policing. Setelah melalui semua proses tersebut maka, akan didapatkan sebuah aliran data yang sesuai dengan apa yang dikomitmenkan kepada penggunanya.

\section{Metodologi}

\subsection{Tempat dan Waktu Penelitian}

Penelitian dan pengambilan data dilakukan di SMK Negeri 7 Jakarta, Jalan Tenggiri, Rawamangun, Jakarta Timur. Adapun waktu penelitian dilaksanakan pada bulan Agustus 2018 sampai dengan bulan Desember 2018. Penulisan laporan skripsi ini dilaksanakan sejak bulan Agustus 2018.

\subsection{Diagram Alir Penelitian}

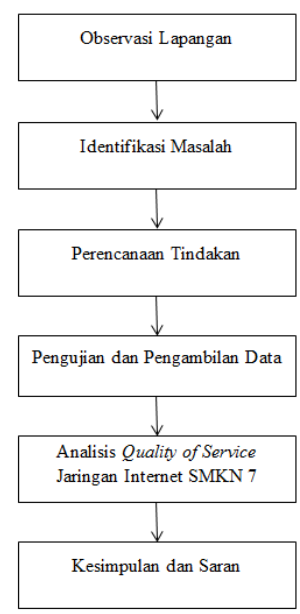

Gambar Error! No text of specified style in document..1. Diagram Alir Penelitian

\section{Observasi Lapangan}

Observasi lapangan merupakan tahapan awal yang dilakukan peneliti dalam penelitian ini. Tujuan dilakukannya observasi lapangan yaitu utuk memperoleh gambaran yang jelas mengenai masalah yang akan dijadikan dasar bahan penelitian. Serta untuk mengenal situasi dan kondisi tempat dilaksanakannya penelitian ini.

\section{Identifikasi Masalah}

Identifikasi masalah merupakan tahapan lanjutan setelah peneliti melakukan observasi lapangan kemudian mengidentifikasi permasalahan yang ada pada penelitian tersebut. Tujuan identifikasi masalah yaitu agar peneliti mendapatkan sejumlah masalah terhadap objek tertentu dalam situasi tertentu yang berhubungan dengan judul penelitian.

\section{Perencanaan Tindakan}

Perencanaan tindakan adalah suatu tahap dimana peneliti dapat mengidentifikasi masalah yang muncul kemudian di analisa secara mendalam dan menyeluruh, maka akan ditemukan pokok permasalahan yang ada . Pada fase ini peneliti membuat peyusunan rencana atau langkah-langkah untuk melakukan penelitian terkait masalah yang muncul.

\section{Pengujian dan Pengambilan Data}

Pengujian dan pengambilan data merupakan suatu tahapan untuk melakukan pengujian terhadap objek yang akan diteliti untuk mendapatkan data yang real dan konkret. Pengujian dan pengambilan data tentunya harus mengikuti perencanaan tindakan yang telah dibuat pada tahapan sebelumnya. Pengujian dilakukan sesuai dengan parameter-parameter yang telah ditentukan.

\section{Analisis Quality of Service Pada Jaringan Internet SMK Negeri 7}

Pada tahap ini peneliti melakukan sebuah analisis tentang pengujian data yang diambil pada jaringan Internet SMK 7. Dalam proses analisis ini standarisasi TIPHON menjadi tolak ukur dalam 
penentuan baik atau tidaknya jaringan Internet SMKN 7 Jakarta.

\section{Kesimpulan Dan Saran}

Setelah peneliti mendapatkan hasil dari pengujian data yaitu berupa data pengukuran bandwidth, throughput, delay dan packet loss serta hasil analisis pengujian tersebut, maka akan dibuat kesimpulan dan solusi atas permasalahan yang terjadi. Membuat kesimpulan dan saran merupakan tahap terakhir dalam penelitian ini.

\section{Hasil dan Analisis}

Berdasarkan hasil analisis dari ke 4 parameter yaitu, throughput, delay, packet loss dan jitter kita bisa mendapatkan hasil akhir dari penelitian ini.

Tabel 4.1. Hasil Analisis Akhir Dari Seluruh Parameter

\begin{tabular}{|c|c|c|c|c|c|}
\hline $\begin{array}{c}\text { Worksta } \\
\text { tion }\end{array}$ & Website & $\begin{array}{c}\text { Rata-rata } \\
\text { Throughp } \\
\text { ut (bps) }\end{array}$ & $\begin{array}{l}\text { Present } \\
\text { ase (\%) }\end{array}$ & $\begin{array}{l}\text { Kategori } \\
\text { TIPHON }\end{array}$ & $\begin{array}{l}\text { Nil } \\
\text { ai }\end{array}$ \\
\hline \multirow{2}{*}{$\begin{array}{c}\text { R. Tata } \\
\text { Usaha }\end{array}$} & $\begin{array}{c}\text { www.facebook.c } \\
\text { om }\end{array}$ & 457942 & 22,8 & Buruk & 1 \\
\hline & www.viva.co.id & 463592 & 23,1 & Buruk & 1 \\
\hline \multirow{2}{*}{$\begin{array}{l}\text { LAB } \\
\text { TKJ3 }\end{array}$} & $\begin{array}{c}\text { www.facebook.c } \\
\text { om }\end{array}$ & 323151 & 10,7 & Buruk & 1 \\
\hline & www.viva.co.id & 329882 & 10,9 & Buruk & 1 \\
\hline \multirow{2}{*}{$\begin{array}{l}\text { LAB } \\
\text { MM2 }\end{array}$} & $\begin{array}{c}\text { www.facebook.c } \\
\text { om }\end{array}$ & 294091 & 9,83 & Buruk & 1 \\
\hline & www.viva.co.id & 296298 & 9,87 & Buruk & 1 \\
\hline $\begin{array}{c}\text { Worksta } \\
\text { tion }\end{array}$ & Website & $\begin{array}{c}\text { Rata-rata } \\
\text { Delay } \\
(\mathrm{m} / \mathrm{s})\end{array}$ & $\begin{array}{c}\text { Prese } \\
\text { ntase } \\
(\%)\end{array}$ & $\begin{array}{l}\text { Kategori } \\
\text { TIPHON }\end{array}$ & Nilai \\
\hline \multirow{2}{*}{$\begin{array}{c}\text { R. Tata } \\
\text { Usaha }\end{array}$} & $\begin{array}{c}\text { www.facebook.c } \\
\text { om }\end{array}$ & 69,15 & - & $\begin{array}{l}\text { Sangat } \\
\text { Bagus }\end{array}$ & 4 \\
\hline & www.viva.co.id & 66,95 & - & $\begin{array}{l}\text { Sangat } \\
\text { Bagus }\end{array}$ & 4 \\
\hline \multirow{2}{*}{$\begin{array}{l}\text { LAB } \\
\text { TKJ3 }\end{array}$} & \begin{tabular}{|c|}
$\begin{array}{c}\text { www.facebook.c } \\
\text { om }\end{array}$ \\
\end{tabular} & 80,1 & - & $\begin{array}{l}\text { Sangat } \\
\text { Bagus }\end{array}$ & 4 \\
\hline & www.viva.co.id & 80,2 & - & $\begin{array}{l}\text { Sangat } \\
\text { Bagus } \\
\end{array}$ & 4 \\
\hline \multirow{2}{*}{$\begin{array}{l}\text { LAB } \\
\text { MM2 }\end{array}$} & $\begin{array}{c}\text { www.facebook.c } \\
\text { om }\end{array}$ & 88,6 & - & $\begin{array}{l}\text { Sangat } \\
\text { Bagus } \\
\end{array}$ & 4 \\
\hline & www.viva.co.id & 99,1 & - & $\begin{array}{l}\text { Sangat } \\
\text { Bagus }\end{array}$ & 4 \\
\hline $\begin{array}{c}\text { Worksta } \\
\text { tion }\end{array}$ & Website & $\begin{array}{c}\text { Rata-rata } \\
\text { Packet } \\
\text { Loss }\end{array}$ & $\begin{array}{c}\text { Prese } \\
\text { ntase } \\
(\%)\end{array}$ & $\begin{array}{l}\text { Kategori } \\
\text { TIPHON }\end{array}$ & Nilai \\
\hline \multirow{2}{*}{$\begin{array}{c}\text { R. Tata } \\
\text { Usaha }\end{array}$} & $\begin{array}{c}\text { www.facebook.c } \\
\text { om }\end{array}$ & 135 & 26,6 & Buruk & 1 \\
\hline & www.viva.co.id & 140 & 27,7 & Buruk & 1 \\
\hline \multirow{2}{*}{$\begin{array}{l}\text { LAB } \\
\text { TKJ3 }\end{array}$} & $\begin{array}{c}\text { www.facebook.c } \\
\text { om }\end{array}$ & 151 & 29,7 & Buruk & 1 \\
\hline & www.viva.co.id & 154 & 30,4 & Buruk & 1 \\
\hline \multirow{2}{*}{$\begin{array}{l}\text { LAB } \\
\text { MM2 }\end{array}$} & $\begin{array}{c}\text { www.facebook.c } \\
\text { om }\end{array}$ & 142 & 28 & Buruk & 1 \\
\hline & www.viva.co.id & 144 & 28,4 & Buruk & 1 \\
\hline & & & & & \\
\hline $\begin{array}{c}\text { Worksta } \\
\text { tion }\end{array}$ & Website & $\begin{array}{c}\text { Average } \\
\text { Jitter } \\
(\mathrm{m} / \mathrm{s})\end{array}$ & $\begin{array}{c}\text { Prese } \\
\text { ntase } \\
(\%)\end{array}$ & $\begin{array}{l}\text { Kategori } \\
\text { TIPHON }\end{array}$ & Nilai \\
\hline $\begin{array}{c}\text { R. Tata } \\
\text { Usaha }\end{array}$ & - & 9,02 & - & Bagus & 3 \\
\hline \begin{tabular}{l|} 
LAB \\
TKJ3
\end{tabular} & - & 10,23 & - & Bagus & 3 \\
\hline $\begin{array}{l}\text { LAB } \\
\text { MM2 }\end{array}$ & - & 9,96 & - & Bagus & 3 \\
\hline \multicolumn{5}{|c|}{ Total Nilai } & 45 \\
\hline \multicolumn{5}{|c|}{ Nilai Indeks QoS } & 2.14 \\
\hline
\end{tabular}

Berdasarkan hasil akhir dari seluruh parameter pada tabel 4.1 didapatkan indeks nilai akhir sebesar 2.14. Nilai indeks ini ada dikisaran sedang pada predikat kategori TIPHON. Hasil ini dapat disimpulkan bahwa kualitas layanan jaringan SMK Negeri 7 Jakarta masih belum sesuai yang diharapkan. Oleh karena itu maintenance system secara berkala, kapasitas bandwidth yang masih terlampau kecil perlu ditambah atau dinaikkan. Serta, management bandwidth yang bagus sangat dibutuhkan oleh jaringan karena dengan pemeliharaan yang baik akan didapat hasil yang baik pula.

\section{Kesimpulan dan Saran}

\subsection{Kesimpulan}

Berdasarkan hasil analisis serta pengukuran dan pembahasan yang telah dipaparkan sebelumnya maka dapat ditarik kesimpulan sebagai berikut :

1. Penerapan mikrotik routerboard RB750Gr3hEX sebagai router server, dianggap masih kurang optimal karena masih banyak kendala yang terjadi pada jaringan internet SMK Negeri 7 Jakarta ketika trafik jaringan sedang padat hasil dari parameter QoS tidak semuanya berkategori bagus.

2. Hasil pengukuran bandwidth menunjukkan hasil yang buruk hal ini diperlukan peningkatan atau penambahan kapasitas bandwidth karena total keseluruhan bandwidth jaringan internet SMK Negeri 7 Jakarta hanya $20 \mathrm{Mbps}$.

3. Hasil pengukuran delay menunjukkan hasil yang sangat bagus hanya saja masih terjadi naik turunnya nilai delay yang membuat jaringan internet tidak stabil.

4. Hasil pengukuran packet loss menunjukkan hasil yang buruk dikarenakan trafik yang begitu padat sehingga terjadinya congestion. Serta penumpukan paket data hingga melampaui kapasitas.

5. Hasil pengukuran jitter menunjukkan hasil yang memuaskan masuk dalam kategori bagus berdasarkan standarisasi QoS versi TIPHON (Telecommunications and Internet Protocols Harmonization Over Network).

6. Nilai Indeks QoS TIPHON secara keseluruhan jaringan Internet SMK Negeri 7 Jakarta adalah 2,14 dan masuk dalam kategori sedang. Maka dapat disimpulkan bahwa Quality of Service Jaringan Internet pada SMK Negeri 7 Jakarta masih belum sesuai yang diharapkan yaitu masuk pada kategori sangat bagus bernilai indeks 3,8 - 4 .

\subsection{Saran}

Demi kelanjutan penelitian yang akan datang, saran yang diajukan oleh penulis setelah melakukan penelitian adalah sebagai berikut :

1. Perlu dilakukan maintenance system secara berkala oleh pihak SMK Negeri 7 Jakarta guna untuk memelihara hardware agar tidak terjadi downtime pada jaringan. 
2. Untuk pengembangan dalam skripsi ini perlu dilakukan penelitian lebih lanjut, seperti melakukan pengukuran pada saat intensitas trafik sedang sedikit atau pada saat trafik jaringan sedang kosong. Untuk mengidentifikasi masalah-masalah lain yang mungkin timbul.

3. Perlu dilakukan bandwidth management yang lebih terorganisir. Metode simple queue masih kurang efektif dalam penggunaannya karena dalam penggunaannya user masih bisa mendominasi jaringan.

4. Perlu melakukan upgrade spesifikasi router server dengan spesifikasi yang lebih tinggi. Upaya untuk meningkatkan kualitas layanan jaringan internet SMK Negeri 7 Jakarta

\section{Daftar Pustaka:}

Cahyadi A., Seto dkk. 2013. Analisis Quality of Service (QoS) Pada Jaringan Lokal Session Initiation Protocol (SIP) Menggunakan GNS3[skripsi]. Semarang: Jurusan Teknik Elektro, Universitas Diponegoro Semarang.

Cisco. 1999. CISCO IOS 12.0 Quality of Service. Indianapolis USA: Cisco Systems Inc.

Darma dkk. 2009. Buku Pintar Menguasai Internet. Jakarta. Mediakita.

Haryanto V., Edy. 2012. Jaringan Komputer. Yogyakarta. ANDI OFFSET.

Iskandar, Iwan \& Hidayat, Alvinur. 2015. Analisa Quality of Service (QoS) Jaringan Internet Kampus (Studi Kasus : UIN Suska Riau). Pekanbaru. Jurnal CoreIT.

Kerlinger. 2006. Metode Eksperimen. Diakses pada tanggal 8 Oktober 2018, dari (https://www.eurekapendidikan.com/2015/ $11 /$ metode-penelitianeksperimen.html)

Laquey, Tracy. 1997. Sahabat Internet : Pedoman bagi pemula untuk memasuki dunia internet. Bandung: Institut Teknologi Bandung

Lubis S., Rahmad \& Pinem, Maksum. 2014. Analisis Quality of Service (QoS) Jaringan Internet di SMK TELKOM Medan. Medan; Sigunda Ensikom

Putri T., Nurdina dkk. 2012. Analisis Quality of Service $(Q o S)$ Jaringan Internet Pada SMK Negeri 4 Palembang[skripsi]. Palembang: Universitas Bina Darma.

Sofana, Iwan. 2009. CISCO CCNA dan jaringan komputer. Bandung: Informatika.

Sofia, Hanna \& Prianto, Budhi. 2010. Panduan Mahir Akses Internet. Jakarta. Kriya Pustaka

Tiphon."Telecommunications and Internet Protocol Harmonization Over Networks (TIPHON) General aspects of Quality of
Service (QoS)", DTR/TIPHON-05006 (cb0010cs.PDF). 1999.

Wulandari, Rika. 2016. Analisis QoS (Quality of Service) Pada Jaringan Internet (Studi

Kasus : UPT Loka Uji Teknik Penambangan Jampang Kulon LIPI). Sukabumi. Jurnal Teknik Informatika dan Sistem Informasi.

Yanto. Analisis QoS (Quality of Service) Pada Jaringan Internet (Studi Kasus: Fakultas Teknik Universitas Tanjungpura)[skripsi]. Tanjungpura : Jurusan Teknik Elektro, Fakultas Teknik, Universitas Tanjungpura.

Yovita V., Leanna dkk. 2015. Jaringan Komputer dan Data Lanjut. Bandung. ISBN.

Yuhefizar. 2008. 10 Jam Menguasai Internet Teknologi dan Aplikasinya. Jakarta. PT. Elex Media Komputindo 